\title{
EM TEMPOS DE FASCISMO SOCIAL, CALAR É CONSENTIR: DIREITOS HUMANOS NO CONTEXTO DO CURSO DE DIREITO DA UNIVERSIDADE FEDERAL DO RIO GRANDE/RS E A REALIDADE DENUNCIADA POR BOAVENTURA DE SOUSA SANTOS
}

\author{
IN TIMES OF SOCIAL FASCISM, SHUT IS CONSENT: \\ HUMAN RIGHTS IN THE CONTEXT OF LAW COURSE OF THE \\ UNIVERSIDADE FEDERAL DO RIO GRANDE / RS AND REALITY \\ DENOUNCED BY BOAVENTURA DE SOUSA SANTOS
}

Jean Lucca de Oliveira Becker ${ }^{1}$

Renato Duro Dias ${ }^{2}$

\begin{abstract}
RESUMO: Este artigo problematiza a educaçăo superior jurídica e as potencialidades que o ensino do direito pode trazer para a pós-modernidade, especialmente as práticas em direitos humanos. Em tempos de fascismo em que índices de intolerância, violência e desagregaçăo social se expressam de maneira acentuada, calar é consentir. Neste sentido, a educaçâo năo pode ser vista nem tratada de forma isolada e desconexa com os outros contextos, envolvendo, assim, aspectos da dupla obrigaçấo política qual seja, vertical e horizontal, na qual nos encontramos. Igualmente, o Curso de Direito da Universidade Federal do Rio Grande - FURG, no Rio Grande do Sul, neste conjunto, parece estar comprometido com a transformaçáo das relaçōes sectárias que definem a sociedade contemporânea. A Universidade deve ter por responsabilidade e princípio o fomento de novas formas de açâo e interaçấo pautadas pela solidariedade e pelo trabalho colaborativo, com vistas a consolidar uma prática social que priorize o cuidado com o outro, fortalecendo os sentimentos de pertença, segurança e confiança. Um processo de democratizaçăo, descolonizaçăo e desmercadorizaçăo que objetiva, sobretudo, a construçâo de ensino jurídico baseado nos direitos humanos e na justiça social.A investigaçâo de abordagem qualitativa está alicerçada em uma revisăo de literatura e na análise das mensagens sociológicas expressas nos documentos curriculares, projetos políticos pedagógicos e planos de ensino.
\end{abstract}

Palavras-chave: Fascismo. Violência. Direitos Humanos. Educaçăo Jurídica. Universidade.

1 Mestrando em Direito e Justiça Social daUniversidade Federal do Rio Grande-FURG.E-mail:jeanbecker@ live.com.pt

2 Pró-Reitor de Graduaçâo da Universidade Federal do Rio Grande - FURG. Doutor em Educaçăo. E-mail: renatodurodias@gmail.com 
ABSTRACT: This paper discusses the legal higher education and the potential that the law education can bring to post-modernity, especially the practices in human rights. In fascism times where intolerance indices, violence and social breakdown are expressed sharply, silence is consent. In this sense, education can not be seen or treated in isolation and disconnected way with other contexts, involving, well, aspects of dual obligation policy which is, vertical and horizontal, in which we find ourselves. Likewise, the Law Course of the Universidade Federal do Rio Grande FURG, in Rio Grande do Sul, this set seems to be committed to the transformation of sectarian relationships that define contemporary society. The University shall have the responsibility and beginning the development of new forms of action and interaction guided by solidarity and collaborative work, with a view to consolidating a social practice that prioritizes care for the other, strengthening the sense of belonging, confidence and trust. A process of democratization, decolonization and decommodification which aims, above all, the construction of legal education based on human rights and social justice.

Keywords: Fascism. Violence. Human Rights. Legal Education. University.

\section{INTRODUÇÃO}

No dia 09 de maio de 2011, o sociólogo português Boaventura de Sousa Santos participou, no Plenário da Assembleia Legislativa do Estado do Rio Grande do Sul, do programa "Destinos e Açóes para o Rio Grande". O tema abordado foi "Intolerância: Violência e Desagregaçâo Social". O debate firmado nesta palestra serve como ponto de partida paraeste artigo, pois mais do que tratar de acontecimentos específicos, o autor aborda as condiçōes de exercício da democracia e da cidadania. Uma análise da realidade conjuntural que se revela de suma importância para o aprofundamento do debate em torno de uma reflexăo necessária que potencialize a construçâo de outro mundo possível, em que a educaçăo superior jurídica, principalmente aquela desenvolvida no âmbito da Faculdade de Direito da Universidade Federal do Rio Grande - FURG, possa estar em consonância com os ditames de um campo de saber dialógico que se preocupa com a reflexăo crítica e humanista, e que, sobretudo, orienta práticas e açôes desenvolvidas em todos os contextos educativos, fundamentando as açóes da Universidade para relaçôes mais solidárias e construtivas, cujos resultados reforçam o compromisso com os diferentes contextos e sujeitos com os quais a Instituiçâo interage, na busca da educaçăo pública de qualidade e da emancipaçăo social.

Pretende-se com este artigo apresentar algumas possibilidades de novas escrituras curriculares expressas em um contexto em que as práticas em direitos humanos descortinam saberes cristalizados. De acordo com Pinsky (2004), năo se trata, como se verá, de uma investigaçấo com uma única resposta, mas com a sugestăo de uma multiplicidade de caminhos possíveis, alguns já desbravados e com muitos transeuntes, outros apenas sugeridos, merecedores de atençâo por parte daqueles que nâo acreditam que respostas a inquietaçóes existenciais encontram-se apenas no fundo de um copo, no uso compulsivo do cartăo de crédito ou no bisturi de um cirurgiăo plástico, mas, principalmente, na solidariedade e na criaçâo de uma sociedade mais digna. 


\section{DEMOCRACIA E CIDADANIA NA CONTEMPORANEIDADE}

Pensar a cidadania no âmbito do Estado-Naçăo ou globalmente considerada é um imperativo imposto pela realidade em que vivemos. Para o sociólogo português Boaventura de Sousa Santos, em conferência realizada em 09 de maio/2011, no Plenário da Assembleia Legislativa do Estado do Rio Grande do Sul, cidadania é um conjunto de direitos que os indivíduos ou grupos detêm por serem membros de uma comunidade específica, uma comunidade política que na modernidade definimos como Estado-Naçâo. Na ocasiâo, o autor afirmou que o conceito envolve a ideia de uma comunidade de pertença coletiva que cria direitos, mas também deveres às pessoas que pertencem a esta comunidade e que se convencionou chamar cidadăos.

Já o conceito originário de democracia, por sua vez, "coincide com o sentido etimológico da palavra, do grego demos, que se traduz por povo e katrein, que significa governo" (BORGES, 2010, p. 13). Assim como um processo de fato, muito mais geral, através do quais relaçôes de poder desigual se transformam em relaçôes de autoridade partilhada,

a edificaçăo da democracia só se verifica quando se sobrepóe a soberania do povo como força propulsora de toda organizaçâo política e social. Só assim cria-se a compreensăo de que o único Poder Legítimo é o Poder Constituinte, tornando, os demais, Poderes Constituídos, isto é, derivados (Executivo, Legislativo e Judiciário). Tenha-se presente também que a soberania do povo, além de constituir os Poderes, cria todo o Direito, edificando a Ordem Jurídica, com os limites dos espaços relacionais entre os homens e entre os homens e o Poder. Só com essa força da soberania popular é possível predicar a Democracia (BORGES, 2010, p. 10).

Portanto, a democracia, apesar de ser um termo da ciência política que "vem sendo objeto de tâo frequentes abusos e distorçōes" (BONAVIDES, 2001, p. 267), é uma baliza que funciona naturalmente em articulaçâo com a cidadania.

Para Boaventura vivemos em um tempo paradoxal em sentido específico. Apesar de sua conferência ter sido proferida no ano de 2011, suas reflexóes permanecem atuais. Afinal, a crise pela qual passa o país seja do ponto de vista moral, política, econômica ou social, nos despe da ideia de que as construçōes do Estado moderno, da democracia e da cidadania estăo baseadas em um conjunto coerente de instituiçôes. É como se elas (instituiçôes) estivessem a aniquilar-se, isto é, a perder sua vitalidade, a incapacidade de corresponder às exigências que os cidadâos lhes fazem, tanto ao nível das práticas democráticas, quanto ao nível do exercício dos direitos de cidadania.

Assim, a mais complexa e paradoxal situaçăo ocorre porque verificamos as açóes de rua, as açôes de protesto, as açôes dos cidadâos que até entâo năo estavam organizados e que, através das redes sociais, se articulam, como se as redes sociais fossem as instituiçôes do futuro - vide as manifestaçôes de junho de 2013. ${ }^{3}$

Esta extra institucionalidade, o sair por fora das instituiçōes, além de ser algo que parece ser parte da vitalidade do nosso tempo, ocorre fundamentalmente porque o

3 Para um melhor aprofundamento, indica-se o livro "Cidades rebeldes: do direito à cidade à revoluçáo urbana" em que os autores analisam as causas e consequências dos protestos que marcaram este período de efervescência popular no país. 
capitalismo global, na sua forma atual definido como neoliberalismo, é um modo de organizaçăo econômica perversa que está, de fato, a tentar corroer as bases do contrato social, que é a "grande narrativa em que se funda a obrigaçăo política moderna ocidental" (SANTOS, 2006, p. 317).

A crise da contratualizaçấo moderna consiste na predominância estrutural dos processos de exclusâo sobre os processos de inclusăo, que foram aqueles que se estabeleceram entre homens e mulheres, a partir de suas lutas, constituindo um esquema de organizaçâo política da democracia e da cidadania: a dupla obrigaçâo política em que nos encontramos.

Para o sociólogo, uma é a obrigaçăo política vertical, dos cidadăos e do Estado: o Estado com seu poder de soberania - os cidadăos com obrigaçôes perante o Estado, e o Estado com obrigaçōes perante os cidadăos. Contudo, tal relaçâo vertical nâo existe sem a outra, horizontal, que é a obrigaçáo cidadâo a cidadáo. É aquilo que nos une por um princípio de fraternidade e solidariedade. Em síntese, temos razóes para pertencemos a uma comunidade e esta identidade, como aquela definida por Bauman (2005), cria uma obrigaçâo horizontal.

O que Boaventura revela é que as duas obrigaçôes, vertical e horizontal, pertencem-se mutuamente. Logo, quando uma se corrói, a outra ou desaparece, ou se atenua. As açôes de violência e intolerância cada vez mais frequentem nos noticiários demonstram os sintomas de que a obrigaçâo cidadăo a cidadâo, isto é, a obrigaçăo horizontal, está a abrir brechas. Mas abre brechas porque a obrigaçăo cidadâo/Estado, a vertical, também está a abrir lacunas.

Portanto, é com este pano de fundo que devemos ver os caminhos da extra institucionalidade, dos indivíduos ou os poderes saírem das instituiçóes, às vezes para promover a democracia no encontro entre as obrigaçôes horizontal e vertical, outras vezes para brecá-la. Quando ocorre o bloqueio nos deparamos como uma sociedade politicamente democrática, porém socialmente fascista.

Pensamento, este, que levou Boaventura a desenvolver, na conferência proferida em Porto Alegre, o conceito de fascismo social. Para ele, é exatamente o resultado da grande concentraçăo de renda, da grande desigualdade social, das grandes formas de discriminaçâo - étnica, racial e sexual -, que conhecemos hoje e que criam relaçóes de poder - para citar Foucault (2014) - tăo desiguais que a parte mais poderosa nestas relaçôes tem o direito de veto sobre a vida dos mais fracos. Assim, quando alguém tem o direito de veto sobre a vida de outro alguém, está configurado o fascismo.

O sociólogo distinguiu cinco formas de fascismo social: a) fascismo contratual; b) fascismo do apartheid social; c) fascismo territorial; d) fascismo financeiro; e) fascismo da intolerância.

O fascismo contratual ocorre em decorrência da

Diferença de poder entre as partes no contrato de direito civil (seja ele um contrato de trabalho ou um contrato de fornecimento de bens ou serviços) é de tal ordem que a parte mais fraca, vulnerabilizada por náo ter alternativa ao contrato, aceita as condiçôes que lhe săo impostas pela parte mais poderosa, por mais onerosas e despóticas que sejam. $O$ projeto neoliberal de transformar o contrato de trabalho num contrato de direito civil como qualquer outro configura uma situaçăo de 
fascismo contratual. Esta forma de fascismo ocorre hoje frequentemente nas situaçōes de privatizaçâo dos serviços públicos, da saúde, da segurança social, da eletricidade, da água, etc. (SANTOS, 2006, p. 335).

O fascismo do apartheid social é a "segregaçâo social dos "excluídos através de uma cartografia urbana dividida em zonas selvagens e zonas civilizadas" (SANTOS, 2006, p. 334). Enquanto estas săo as zonas do contrato social, aquelas sáo as zonas do estado de natureza hobbesiano. O autor cita o exemplo de que para se defenderem, as zonas civilizadas transformam-se em castelos neofeudais, em enclaves fortificados que caracterizam as novas formas de segregaçăo urbana, como os condomínios fechados.

A divisăo entre zonas selvagens e zonas civilizadas está a transformar-se num critério geral de sociabilidade, um novo espaço-tempo hegemônico que atravessa todas as relaçôes sociais, econômicas, politicas e culturais e que por isso é comum à açăo estatal e à açăo năo estatal. Está inscrito, hoje em dia, no coraçăo do quotidiano. No domínio da açáo estatal está a dar origem a uma nova forma de Estado paralelo [...] Julgo que em tempo de fascismo social o Estado paralelo assume uma nova forma. Consiste num duplo padrăo da açăo estatal nas zonas selvagens e nas zonas civilizadas. Nas zonas civilizadas, o Estado age democraticamente, como Estado protetor, ainda que muitas vezes ineficaz ou năo confiável. Nas zonas selvagens, o Estado age fascisticamente, como Estado predador, sem qualquer veleidade de observância, mesmo aparente, do direito. A polícia que ajuda o menino das zonas civilizadas a atravessar a rua é a mesma que persegue e, eventualmente, mata o menino das zonas selvagens (SANTOS, 2006, p. 334).

O fascismo do apartheid social possui outras formas como, por exemplo, o fascismo territorial, "que existe sempre que atores sociais com forte capital patrimonial retiram ao Estado o controle do território onde atuam ou neutralizam este controle, cooptando ou violentando as instituiçôes estatais" (SANTOS, 2006 p. 335). Năo só, mas também exercendo a regulaçấo social sobre os habitantes do território sem a participaçâo destes e contra os seus interesses, fazendo com que o princípio do primado do direito năo vigore.

O fascismo financeiro, por sua vez, corresponde ao fascismo do capital financeiro e das agências de notaçâo que possuem o poder de veto sobre os países, sobretudo os mais pobres.

É talvez a forma mais virulenta de sociabilidade fascista. É o fascismo que comanda os mercados financeiros de valores e de moedas, a especulaçâo financeira global [...] Esta forma de fascismo social é a mais pluralista na medida em que os movimentos financeiros sâo os produtos de decisōes de investidas individuais ou institucionais espalhadas por todo o mundo e, aliás, sem nada em comum senăo o desejo de rentabilizar os seus valores. Por ser o mais pluralista é também o fascismo mais virulento porque o seu tempo-espaço é o mais refratário a qualquer intervençăo democrática (SANTOS, 2006, p. 336).

Por último, mas năo menos importante, o fascismo da intolerância. Para o sociólogo, as desigualdades funcionam em nossa sociedade de par com outro sistema de hierarquia que năo é de riqueza, mas é do estatuto social, é do preconceito, da intolerância perante a diferença. É o que o autor chamou de diferenciaçâo desigual. Há por um lado desigualdade social e econômica e por outro, diferenciaçăo hierárquica desigual em funçâo do sexo - mulheres inferiores aos homens -, de raças - negros inferiores a 
brancos -, de religiōes - esta religiăo é boa e a outra năo, de orientaçóes sexuais - a heterossexualidade deve ser predominante à homossexualidade, etc. Săo diferenciaçôes que criam desigualdade e, consequentemente, alimentam-se mutuamente.

A intolerância é, portanto, prosseguiu Boaventura naquela ocasiâo, uma desumanizaçâo. É a negaçấo da humanidade do outro. E ela existe exatamente porque se assenta em três pilares fundamentais: o preconceito, o interesse e a ideologia.

O preconceito é um senso comum adquirido de inferioridade do outro; da periculosidade do outro, e, assim quando o outro vai para um lado da rua, devo seguir caminho oposto; da ojeriza com a cor do outro, enfim, é a exclusăo, o ódio ao outro "diferente" de mim.

Tais formas de intolerância estâo a aumentar na sociedade exatamente porque à medida que se quebra o vínculo da obrigaçăo política vertical, quebra-se o vínculo da obrigaçaáo horizontal cidadâo a cidadâo. É como se este, na proporçâo da crise do contrato social, conforme referido anteriormente, entra num estado de natureza, numa guerra de todos contra todos. É a cultura do medo e da insegurança capaz de destruir a civilidade.

Para além do preconceito, há uma ideologia que muitas vezes prega a naturalizaçâo da diferença - da inferioridade do outro. Portanto, a desigualdade, como a discriminaçáo nos casos acima referidos, nâo é causa, mas sim consequência. Como se determinado grupo fosse inferior, tem de ser tratado como tal. Isto é da essência da ideologia, mas há sempre um interesse.

A intolerância tem muitas vezes por trás o interesse econômico já que permite desvalorizar a força do trabalho; o preconceito sexual permite desvalorizar o trabalho das mulheres; o preconceito racial desvaloriza o trabalho dos negros; etc. Enfim, Boaventura versou acerca da discriminaçâo a alimentar a desigualdade precisamente porque há um interesse econômico em que aqueles sejam considerados subumanos.

Neste momento de intolerância e do seu crescimento, o grande problema que enfrentamos é o seu contrário, isto é, a tolerância. Se observarmos epistemologicamente, tolerar é aguentar o que é desagradável, o que nâo gostamos o que náo podemos evitar e, por isto, toleramos. Assim, prosseguiu o sociólogo, toda ideia de tolerância se assenta num processo de poder em que tenho o direito de designar o que é tolerável e o que năo é tolerável. O que năo tem poder nâo tem direito de fazer esta distinçăo. Logo, tal critério do que é tolerável e o que é intolerável năo permite, de maneira nenhuma, conhecer o outro e sua diferença. A tolerância tem, portanto, esta arrogância implícita.

Desta forma, em tempos de fascismo social, tolerar é muito pouco. Precisamos năo só reconhecer a diferença, como fazer dela um reconhecimento. É o que o sociólogo chamou de enriquecimento mútuo. Reconhecemos a diferença e enriquecemo-nos com ela. Assim, o autor propóe năo a tolerância, mas o enriquecimento recíproco através dos pressupostos da interculturalidade, que podem ser usados para "significar e representar um processo e projeto político-social transformador" (WALSH, 2009, p. 83).

Há que se citar outra característica de nossos tempos: a violência. Para Boaventura, trata-se da forma mais complexa de fascismo social por se tratar de um fenômeno coletivo e interpessoal. Nâo só, ela mistura bem as desigualdades com a discriminaçấo, pois enquanto as primeiras formas de fascismos eram centradas na desigualdade, e a 
intolerância é mais uma discriminaçăo, a violência mistura os dois. Por isto, torna-se, por vezes, explosiva.

Portanto, a violência, na análise conjuntural do sociólogo, é toda açâo de imposiçâo física. E é assim para impor uma vontade no sentido de manter ou năo o poder sobre o outro de uma maneira impositiva: é um fascismo por ser um direito de veto - direito de incapacitar o outro; incapacitar tirando-lhe a vida; incapacitar ferindo-o.

Por conseguinte, passou-se a distinguirem-se seis formas de violência sobre as quais incidem os estudos na sociedade. Todas elas - no entendimento do autor - estâo sempre na lógica: quebra da obrigaçâo horizontal por consequência da quebra da obrigaçâo vertical, com o Estado. Săo elas as violências doméstica, urbana, racial, rural, escolar e sexual.

A violência doméstica, por exemplo, decorre do patriarcado. Tem esta forma de opressáo com o qual nos acostumamos dentro do novo pensamento de esquerda crítico, que é o capitalismo, o colonialismo e o patriarcado. Configuram-se estes os três grandes pilares da opressăo na sociedade.

A violência urbana, por sua vez, vem do fato de cada vez mais haver pessoas em espaços cada vez mais apinhados, obrigadas a interagir, porém desconhecidas entre si. É isto que está a fazer com que a violência urbana seja de tal ordem, combinada com o sistema da desigualdade.

A violência racial provém do colonialismo. Ela nâo acabou com a descolonizaçâo. É está uma das maiores liçōes dos trabalhos de Boaventura. No seu Centro de Estudos Sociais, na Universidade de Coimbra, há, inclusive, um curso de doutoramento sobre pós-colonialismo e cidadania global que tenta mostrar que o colonialismo, depois das independências, manteve-se sob outra forma e representa, hoje, a luta contra o preconceito e contra a violência racial, muito ligada à intolerância.

A violência rural, obviamente, é gerada pela grande propriedade, instigando as reformas agrárias, combinada com o preconceito contra o índio, contra o afrodescendente quilombola, contra o camponês, contra o ribeirinho, etc. Preconceitos a multiplicarem-se e a ampliarem a desigualdade social.

A violência escolar, por sua vez, possui tentáculos de uma violência institucional cujas causas têm a ver, muitas vezes, com o excesso de institucionalidade, com o excesso de disciplina do corpo, com o excesso da obsessăo pelas didáticas e pelas metodologias e náo pelos seres humanos que estăo em sua frente. Tal diagnóstico encontra respaldo toda vez que nos deparamos com notícias como "PUC rejeita criaçâo da cátedra Foucault". ${ }^{4}$

Todas estas formas de violência sâo diferentes entre si, mas comuns no seu crescimento. E se todas crescem, alguma razăo há de existir para que todas estejam a acender-se na sua diversidade. Para Santos, o motivo tem a ver com o duplo colapso de uma obrigaçáo política vertical - Estado/cidadăo - e horizontal - cidadâo/cidadăo.

4 PALHARES, Isabela. PUC rejeita criaçáo da cátedra Foucault. Primeira universidade fora da França a abrigar áudios do pensador francês, reconhecido crítico da Igreja, pode ter de devolvê-los. Disponível em: 〈http://educacao.estadao.com.br/noticias/geral,puc-rejeita-criacao-da-catedra-foucault,1678638> Acesso em 20 de outubro de 2015. 
A democracia participativa e deliberativa é uma tentativa de democratizar a obrigaçăo política vertical. E ao democratizá-la, horizontaliza, e ao horizontalizá-la fortalece a obrigaçấo cidadăo a cidadâo. Cria novos climas de convivência, novos sistemas de civilidade, mas quando se rompem - temos a atropelamento dos ciclistas como ocorreu em Porto Alegre ${ }^{5}$-, começamos a observar que este tecido nunca é irreversível. As forças do fascismo social estâo à espreita sempre a criar brechas para destruir a obrigaçăo, que é a obrigaçăo do contrato e da inclusăo social. Da inclusăo que é, simultaneamente, uma luta pela igualdade e pelo fim da discriminaçăo.

Boaventura de Sousa Santos concluiu sua conferência năo vendo outra soluçâo, senâo a de tentarmos recuperar, isto é, a reinventarmos as grandes tarefas que podem conduzir na memória das lutas passadas, mas naturalmente reinventando-as no século XXI, com três palavras que o autor propôs para reflexăo: democratizar, descolonizar e desmercadorizar. Para o autor, é palavras-chave para podermos resolver a emergência de fascismos que estâo a minar a democracia e os direitos dos cidadăos, qualquer que seja a forma que eles assumam.

A primeira tarefa para democratizar é democratizar a democracia,

Recusar a ideia de que a democracia liberal representativa é a única forma válida de democracia e legitimar outras formas de deliberaçáo democrática, a já referida demodiversidade; procurar novas articulaçôes entre a democracia representativa e a democracia participativa e, em certos contextos, entre ambas e a democracia comunitária própria das comunidades indígenas e camponesas da África, América Latina e Ásia; estender os campos de deliberaçáo democrática para além do campo político-estatal de modo a evitar que a democracia politica se transforme numa pequena ilha democrática integrada num arquipélago de despotismos (o fascismo social): na fábrica, na família, na rua, na religiâo, na comunidade, nos conhecimentos, nos meios de comunicaçăo, etc. (SANTOS, 2011, p. 141).

Nesta democratizaçăo, que é também a descolonizaçăo, o autor manifesta-se da seguinte maneira:

Descolonizar é um imperativo bem difícil de concretizar. Por um lado, há quem pense que a descolonizaçáo já teve lugar e que por isso o colonialismo é um fato passado. Por outro lado, mesmo admitindo que o colonialismo continua a existir sob outras formas, é sempre possível confundi-lo com outras relaçóes de poder desigual ou justificá-lo em nome de valores ou de exigências prioritárias. Colonialismo é toda a relaçăo de opressâo assente na inferioridade supostamente natural, racial ou étnico-cultural do oprimido. Sáo os mais diversos movimentos que concebem as suas lutas como visando uma ou outra manifestaçáo do colonialismo e propondo alternativas descolonizadoras (SANTOS, 2011, p. 142).

E, finalmente, desmercadorizar,

Desmercadorizar significa impedir que a economia de mercado estenda o seu âmbito a tal ponto que transforme a sociedade no seu todo numa sociedade de mercado,

5 SCIREA, Bruna. Quatro anos após atropelamento de ciclistas em Porto Alegre, avanços ainda săo tímidos. Manifestaçóes do Massa Crítica nesta semana devem marcar o aniversário do atropelamento e cobrar agilidade da Justiça. Disponível em: <http://zh.clicrbs.com.br/rs/porto-alegre/noticia/2015/02/ quatro-anos-apos-atropelamento-de-ciclistas-em-porto-alegre-avancos-ainda-sao-timidos-4706871. html> Acesso em 20 de outubro de 2015. 
numa sociedade onde tudo se compra e tudo se vende, inclusive os valores éticos e as opçóes políticas. O imperativo de dermercadorizar envolve a promoçấo do mais amplo conjunto de iniciativas, muitas delas já testadas pelo tempo e pela capacidade de criar bem-estar para que nelas participam (SANTOS, 2011, p. 145).

Em vista dos argumentos apresentados, conclui-se que a educaçăo, como nâo poderia deixar de ser, encontra-se no centro das necessidades. Afinal, é a ausência histórica de um projeto educacional consistente, uma das principais raízes das mazelas apontadas por Boaventura de Sousa Santos, quer com as formas de fascismos sociais, quer com as manifestaçóes de violências. Nesta seara, questiona-se, qual o papel da educaçăo na construçăo de outro mundo possível? Como construí-la tendo como referência o ser humano? De que maneira utilizá-la enquanto instrumento de promoçăo da cidadania? Enfim, como compor uma educaçâo que realize as transformaçōes necessárias de democratizar, descolonizar e desmercadorizar?

Como bem assegurado por Méazáros (2005),

A nossa tarefa educacional é, simultaneamente, a tarefa de uma transformaçăo social, ampla e emancipadora. Nenhuma das duas pode ser posta à frente da outra. Elas săo inseparáveis. A transformaçăo social emancipadora radical requerida é inconcebível sem uma concreta e ativa contribuiçăo da educaçáo no seu sentido amplo [...] E vice-versa: a educaçăo năo pode funcionar suspensa no ar. Ela pode e deve ser articulada adequadamente e redefinida constantemente no seu interrelacionamento dialético com as condiçôes cambiantes e as necessidades da transformaçáo social emancipadora e progressiva em curso. Ou ambas têm êxito e se sustentam, ou fracassam juntas (MÉAZÁROS, 2005, pp. 76-77).

Neste sentido, o Curso de Direito da Universidade Federal do Rio Grande - FURG parece estar inserido neste contexto, já que problematiza a educaçáo jurídica a partir de uma leitura contextualizada dos direitos humanos e da justiça social.

\section{EDUCAÇÃO SUPERIOR: O CURSO DE DIREITO DA UNIVERSIDADE FEDERAL DO RIO GRANDE, FURG/RS, E SEU CONTEXTO DE INSERÇÃO}

A Educaçăo Superior brasileira, entendida como direito da sociedade e um dever do Estado, deve incorporar em sua razăo de existir um conjunto de funçóes sociais, ampliando o compromisso público com a política de formaçăo e produçâo de conhecimento, uma vez que é um dos principais pilares de emancipaçăo da sociedade, e, por isso, deve reafirmar princípios constitucionais da democracia; assumir a responsabilidade social por meio de açóes que possibilitem aos diferentes grupos sociais o usufruto dos conhecimentos produzidos pela academia em todas as suas dimensóes; e reconhecerse como espaço público, que delineia sua identidade no diálogo com a sociedade.

A Universidade, desta maneira, se constitui como um lugar plural de construçâo de diferentes percepçôes de mundo e, em razâo disso, deve considerar e defender a diversidade e as diferenças como constitutivas das culturas e dos saberes, de forma a fortalecer as identidades do povo brasileiro. Estrutura-se em um conjunto de relaçôes sociais e humanas, um centro de socializaçâo e produçăo de culturas e conhecimentos e, por isto, nâo pode ser concebida fora do contexto da realidade contemporânea como à denunciada por Boaventura de Sousa Santos. 
Nesta conjuntura, a Faculdade de Direito (FADIR), criada em 1960 com a denominaçâo Faculdade de Direito Clóvis Beviláqua (Decreto n. 47.738/1960), em 1969, com a criaçăo da Universidade Federal do Rio Grande - FURG, foi incorporada à mesma, passando a operar a partir do respectivo Departamento de Ciências Jurídicas, hoje extinto. Em 2010, com a nova reestruturaçáo estatutária da Universidade, retomou a denominaçăo histórica de "Faculdade de Direito", passando-a ocupar lugar de destaque entre as unidades acadêmicas da FURG. Com trinta professores, quatro técnico-administrativos e aproximadamente 600 alunos, é responsável, hoje, no plano do ensino, pelo oferecimento dos cursos de Direito matutino e noturno, pelo Curso de Especializaçăo em Educaçăo em Direitos Humanos e pelo recentemente aprovado Mestrado em Direito com área de concentraçâo em Direito e Justiça Social.

Igualmente, oferece o curso de graduaçấo em Relaçôes Internacionais no Campus da FURG, de Santa Vitória do Palmar. Além disto, conta com diversos projetos e programas de extensâo, com destaque especial para o Serviço de Assistência Judiciária (SAJ), para o Centro de Referência em Direitos Humanos (CRDH) e para o Centro de Referência em Apoio as Famílias em situaçâo de pobreza (CRAF). No campo da pesquisa já conta com mais de uma centena de projetos desenvolvidos ou em desenvolvimento, muitos com financiamento das principais agências de fomento.

Portanto, é tendo em vista o objetivo geral do curso de Direito da FURG, qual seja, a formaçáo de cidadáos e operadores conscientes dos valores implícitos nas esferas do Direito Público e Privado, assim como dos limites e interaçōes entre o espaço estatal e o nâo estatal; que se percebam partícipes do processo de construçâo do Direito e da sociedade e que, sem prejuízo de sólida formaçăo geral, pautados em valores éticos, sociais e humanísticos estejam capacitados à atuaçâo político-jurídica, em especial no âmbito regional. E, ainda, atendendo à sua vocaçăo específica, contribuir para que sejam cidadăos e profissionais capazes de defender com zelo especial os Direitos Humanos, Desenvolvimento e Sustentabilidade Socioambiental; é que este trabalho passa a estabelecer conexóes entre as atividades desenvolvidas no âmbito da FADIR com o bloqueio a emergência de fascismos que estâo a minar a democracia e os direitos dos cidadâos, qualquer que seja a forma que eles assumam.

O Centro de Referência em Direitos Humanos da Universidade Federal do Rio Grande (CRDH/FURG), por exemplo, surgiu a partir de experiências realizadas por órgáos públicos e organizaçóes nâo governamentais que possibilitaram o acesso da populaçăo de baixa renda a serviços essenciais como a assistência jurídica e a documentaçâo civil básica. Assim, o CRDH/FADIR/FURG atua como mecanismo de defesa, promoçăo e acesso à justiça e estimula o debate sobre cidadania, influenciando positivamente na conquista dos direitos individuais e coletivos. Deste modo, tendo como ponto de partida atividades que visam à humanizaçăo, à emancipaçăo do ser humano, à transformaçăo social, construindo realidades mais justas e igualitárias, percebe-se aqui o desenvolvimento das três palavras que Boaventura de Sousa Santos propôs para reflexăo: democratizar, descolonizar e desmercadorizar.

Evidente que democratizar a democracia requer a formulaçăo de políticas públicas "em nível mundial, com as variaçōes e adaptaçōes necessárias consoante o país ou a regiấo do mundo. É esta uma das dimensôes mais consistentes da globalizaçăo contra hegemônica" (SANTOS, 2011, p. 141). No caso da FURG, tendo a vocaçấo voltada 
aos ecossistemas costeiros e oceânicos, tem suas açóes pautadas no princípio básico da indissociabilidade entre o ensino, a pesquisa e a extensăo, na formaçăo de profissionais, na produçáo e socializaçăo de conhecimentos e tecnologias e que com essa interaçăo, a Instituiçăo rege sua funçăo social, comprometida com o desenvolvimento de políticas inovadoras voltadas para as necessidades locais, regionais, nacionais e globais, na busca de melhor qualidade de vida; o CRDH/FADIR/FURG conta com profissionais que proporcionam atendimento jurídico, social e psicológico, que consiste na prestaçăo de assistência, orientaçăo, encaminhamento e acompanhamento jurídico, social, antropológico e psicológico. Dentre os serviços prestados incluem-se ainda a capacitaçăo e a produçăo de conhecimento em Direitos Humanos, bem como o apoio a qualquer atividade que tenha como objetivo a integraçăo social e a disseminaçấo de conhecimentos ligados à área de abrangência do projeto.

Nesta democratizaçâo, que é também a descolonizaçâo, através do CRDH/ FADIR/FURG, verifica-se um exitoso respeito à diversidade humana. Afinal, a Universidade, como espaço de pluralidade de pensamento e diferentes percepçóes de mundo e opçóes, considera a diversidade e as diferenças como constitutivas das culturas e dos saberes, defendendo o respeito à diversidade étnico-racial, de gênero, de orientaçáo sexual e de crenças espirituais. Pois, como dito anteriormente, em tempos de fascismo social, tolerar é muito pouco. Precisamos năo só reconhecer a diferença, como fazer dela um reconhecimento. Foi o que Boaventura denominou de enriquecimento mútuo. Reconhecemos a diferença e enriquecemo-nos com ela através dos pressupostos da interculturalidade. Os Centros de Referência em Direitos Humanos deverăo ser uma Casa de Direitos, de convivência entre pessoas. Um espaço físico onde săo implementadas açôes que visam à defesa e a promoçăo dos Direitos Humanos.

Desmercadorizar, em que pese ser "um imperativo incontornável na busca de uma sociedade melhor" (SANTOS, 2011, p. 141), sobrepostas às crises financeira, econômica e social que acompanham o capitalismo desde o seu início, as crises ecológica, energética e alimentar vieram a conferir um grau de convicçâo maior a algumas constataçôes que até entăo năo tinham merecido a atençăo do cidadăo comum. Por isto, cita-se aqui náo apenas o CRDH/FADIR/FURG, mas também discussōes postas no Mestrado em Direito através da disciplina de economia solidária, instrumento de promoçăo de formas de economia social como cooperativas, sistemas de entreajuda e de troca de tempo e trabalho.

Náo só, para fazer frente ao duplo colapso de uma obrigaçâo política vertical Estado/cidadáo - e horizontal - cidadăo/cidadăo, o Mestrado em Direito e Justiça Social da FADIR/FURG, tem procurado desenvolver estudos críticos e interdisciplinares sobre as relaçôes entre Direito e Justiça Social, enfrentando questôes que relevam da igualdade de direitos, da solidariedade e da sustentabilidade, aprofundando o debate científico que articula as alternativas para o desenvolvimento sustentável e a igualdade de oportunidades nas sociedades multiculturais do mundo globalizado. Para o profissional do Direito destaca-se o grande desafio da cidadania em face da complexidade da vida em sociedade.

O requisito de responsabilidade social atribuído às Instituiçōes de Ensino Superior encontra-se em consonância com a formaçăo de cidadăos críticos e conscientes de 
seu papel, aptos para entenderem o contexto econômico-social e político-jurídico das demandas e do mundo atual, onde o Direito năo é apenas produto da sociedade, mas, também, nas liçôes de Santos (2003), deve ser encarado como um espaço de construçâo de emancipaçăo e crítica social. Assim, ele (o Direito) deve estar comprometido com a promoçăo da cidadania o que implica em superar, juridicamente, a falsa dicotomia entre direitos de liberdade de um lado e direitos de igualdade de outro. O pluralismo jurídico nos permite refletir sobre as possibilidades de incorporaçăo jurisprudencial de soluçôes de conflitos sociais fundamentadas em valores humanitários, comprometidas com a ética pública e a justiça social.

Neste sentido, o Mestrado da FADIR/FURG conta com duas linhas de pesquisa: i) a realizaçấo constitucional da solidariedade e, ii) as políticas públicas de sustentabilidade.

Com relaçăo à primeira, a experiência brasileira de transiçăo democrática se notabilizou pela adoçâo de uma nova Constituiçâo que contou com uma efetiva participaçăo popular no processo constituinte. Nessa perspectiva, a noçâo de cidadania assume desde entâo o compromisso com a efetividade dos direitos constitucionalmente reconhecidos e juridicamente protegidos. A particularidade da Constituiçáo brasileira seria justamente a sua abertura para um projeto político-constitucional de correçăo das desigualdades sociais e econômicas. A correta aplicaçăo do direito desafia as possibilidades de consolidaçáo da democracia brasileira. Cotidianamente, as normas jurídicas sâo questionadas náo somente quanto à sua existência, mas, sobretudo, quanto a sua real possibilidade de transformaçáo social. O profissional do direito, no contexto brasileiro, deve incorporar ao conhecimento da norma jurídica um valor ético e político capaz de atender às expectativas da sociedade, brecando as formas de fascismo e violência social.

Já com relaçăo à segunda, na democracia constitucional o poder público assume o compromisso de promover políticas públicas capazes de transformar a realidade caracterizada pelas desigualdades sociais e econômicas persistentes. A presença da administraçâo pública nas relaçóes sociais deixa de ser uma opçâo política governamental, tornando-se uma exigência constitucional de promoçấo dos direitos de cidadania. Doravante a exigência de promoçăo da cidadania năo se limitará aos direitos civis e políticos, mas implicará na obrigaçăo de promoçâo dos direitos sociais, econômicos e culturais. A realidade multicultural da sociedade brasileira exige que o direito enfrente questôes complexas que envolvem desde a promoçâo da igualdade de oportunidades até a constataçấo ou reconhecimento de universos jurídicos distintos, tais como os das sociedades indígenas e quilombolas. A relaçăo do homem com a natureza exige a adoçăo de políticas públicas de estímulo à sustentabilidade do desenvolvimento.

O CRDH/FADIR e o Mestrado em Direito e Justiça Social constituem açōes num sentindo macro das tarefas de democratizar, descolonizar e desmercadorizar. Mas em que pese "o modo como se define uma crise e se identificam os fatores que a causam tem um papel decisivo na escolha de medidas que a superem e na distribuiçâo dos custos que estas possam causar" (SANTOS, 2011, p. 15), por vivermos em um tempo paradoxal em sentido específico, conforme dissertado anteriormente, calcado, muitas vezes, pela intolerância, violência e desagregaçáo social, requer da Faculdade 
de Direito da Universidade Federal do Rio Grande açóes também num sentido micro como, por exemplo, no cotidiano da sala de aula.

A luta pela definiçăo da crise é assim, um ato iminentemente político e para esclarecer sua natureza é preciso algum esforço analítico. Boaventura esclareceu que ela (crise) consiste na predominância estrutural dos processos de exclusăo sobre os processos de inclusăo. Logo, a inclusâo social como princípio orientador das açôes educativas da FURG, deve reafirmar a preocupaçăo e o compromisso com a democratizaçâo e a promoçấo da equidade de condiçóes de acesso ao conhecimento e de permanência de grupos em situaçâo de vulnerabilidade social e/ou especial, nos mais diversos níveis de ensino, reconhecendo os limites e deficiências humanas como novas potencialidades criadoras de aprendizagem, na busca da formaçăo cidadă, na defesa da democracia e do direito a diferença.

A dupla obrigaçăo política em que nos encontramos, vertical e horizontal, quando bloqueadas, origina uma sociedade politicamente democrática, porém socialmente fascista. Mas năo só, violenta. Para o sociólogo, trata-se da forma mais complexa de fascismo social por se tratar de um fenômeno coletivo e interpessoal. Ela mistura bem as desigualdades com a discriminaçăo, pois enquanto as primeiras formas de fascismos eram centradas na desigualdade, a violência mistura os dois.

Por conseguinte, passou-se a distinguirem-se seis formas de violência sobre as quais incidem os estudos na sociedade. Todas elas - no entendimento de Boaventura estăo sempre na lógica: quebra da obrigaçăo horizontal por consequência da quebra da obrigaçâo vertical, com o Estado. Sáo elas as violências doméstica, urbana, racial, rural, escolar e sexual.

A contextualizaçáo destas formas de violência ocorrem a partir da flexibilizaçáo curricular, que pressupóe um currículo entendido como processo formativo, dinâmico e em permanente movimento, permitindo que a açăo educativa da Universidade incorpore outras formas de aprendizagem e de produçăo do conhecimento presentes na realidade social.

Assim, a violência doméstica e sexual é abordada, diretamente, a partir de disciplinas como "Direito e Gênero", que procura problematizar as representaçôes de gênero na sociedade; feminismo; violência de gênero; lei Maria da Penha, convençóes e tratados internacionais relativos ao tema, etc. e "Direitos Humanos", que procura problematizar o exercício da cidadania na construçăo de novos dir eitos fundamentais.

A contextualizaçâo das violências urbana, racial e rural, por sua vez, se dá através de uma rede de disciplinas: "Ciência política, Estado e Constituiçăo"; "Direito Penal"; "Sociologia Geral"; "Psicologia aplicada ao Direito"; "Direito Processual Penal"; "Mediaçâo de Conflitos"; "Direito Penitenciário"; "Sistemas Processuais Penais"; "Criminologia"; "Legislaçăo Penal Extravagante"; "Fundamentos de Filosofia"; "Antropologia Filosófica"; "Filosofia e Ética jurídica"; "Direito Civil"; "Direito Processual Civil" e "Dogmática Jurídica”.

Já a violência escolar, além de abarcar, quer de uma ou de outra forma as disciplinas mencionadas acima, também é retratada diretamente em disciplinas como "Direito Educacional", que procura propiciar um processo de ensino-aprendizagem reflexivo, crítico e pluridisciplinar sobre Direito Educacional, sobretudo, com ênfase 
nos estudos sobre Direito à Educaçăo como Direito fundamental, Políticas Públicas Educativas e Ensino Jurídico na Contemporaneidade; estudar a legislaçâo, as políticas educacionais e a realidade educacional em sua relaçâo com a estrutura política, econômica e social; desenvolver estudos sobre os sistemas educacionais, visando construir instrumentos que permitam exercer a crítica com objetividade, possibilitando a tomada de posiçôes e o exercício da análise constante das transformaçôes da realidade educacional e social e o desenvolvimento de análises críticas sobre educaçâo, currículo e pedagogia jurídica, necessárias à formaçăo do bacharel em Direito como agente de transformaçăo social.

Nâo só, menciona-se o grupo de estudos "Quem tem medo de Foucault", pois, já que violência escolar, de acordo com Boaventura, possui tentáculos de uma violência institucional cujas causas têm a ver, muitas vezes, com o excesso de institucionalidade, com o excesso de disciplina do corpo, com o excesso da obsessăo pelas didáticas e pelas metodologias e năo pelos seres humanos, estudar este autor revela-se como um potente marco teórico-metodológico para descortinar as relaçóes de saber e poder disciplinário no campo da educaçâo jurídica.

Enfim, o que está em jogo năo é apenas a modificaçăo política dos processos educacionais - que praticam e agravam as formas de fascismos e violências - mas também a reproduçáo das estruturas de valores que contribui para impedir o desenvolvimento das tarefas de democratizar, descolonizar e desmercadorizar.

\begin{abstract}
Estas săo as exigências teóricas das quais viemos, e devemos ver quais săo as consequências politicas e quais sáo os instrumentos com que contamos. A mensagem foi sempre que necessitamos de um conhecimento muito sofisticado e exigente, porque temos de conhecer muito bem a tradiçăo e ao mesmo tempo contestá-la, enfrentá-la e inovar a partir desta tradiçăo. Roberto Fernández Retamar, um grande crítico literário cubano, costuma dizer que temos uma dupla tarefa, sobretudo a partir da situaçăo pós-colonial: por um lado, a de conhecer muito bem o centro hegemônico e, por outro, a de conhecer muito bem a alternativa ao centro hegemônico. Ou seja: devemos gerar um duplo conhecimento que é fundamental para todos nos, sobretudo para os jovens cientistas sociais de hoje (SANTOS, 2007, pp. 83-84).
\end{abstract}

Assim, a par das múltiplas contradiçōes postas na sociedade atual, a FADIR/FURG precisa situar-se de modo crítico e dialético, dialogando efetivamente com todos os setores da sociedade, a partir de um contexto local, incluído na problemática nacional, que, por sua vez, determina e é determinante de uma conjuntura global, de um lado, contribuindo para o desenvolvimento tecnológico contemporâneo e, de outro, servindo a uma concepçâo radical e universal de cidadania.

O compromisso da Universidade Pública materializa-se em açōes que possibilitam a participaçăo dos diversos grupos sociais, num esforço coletivo tanto daqueles que fazem parte da Universidade, quanto dos que participam dos diferentes segmentos sociais, na busca de soluçóes de problemas que afetam essa sociedade no presente e, assim, contribuir para o planejamento e execuçâo responsável de açôes futuras. Orientando-se nessa perspectiva, a FADIR/FURG, enquanto uma Instituiçáo Pública, precisa ser pensada pela sua capacidade de produçâo de conhecimentos e inovaçăo, mas, sobretudo, pela filosofia que rege a vida coletiva desta Instituiçăo e sua relaçăo com a Sociedade. 


\section{CONSIDERAÇÕES FINAIS}

Os riscos que corremos em face da erosâo do contrato social, através do bloqueamento entre as obrigaçóes vertical e horizontal săo demasiado sérios para que ante eles cruzemos os braços. "Há, pois, que buscar alternativas de sociabilididade que neutralizem ou previnam estes riscos e abram o caminho a novas possibilidades democráticas" (SANTOS, 2006, p. 338). Năo se trata, evidentemente, de uma tarefa fácil dado que a desregulaçăo social provocada por esta crise e que se expressa através das formas fascismos e violências é tăo profunda que acaba por desregular as próprias resistências aos fatores de crise e as exigências emancipatórias que lhe dariam sentido.

Igualmente, a partir deste trabalho, é possível constatar a íntima relaçâo entre os processos educacionais e os processos sociais. Assim como em Mészáros (2005), entendemos que educar năo é mera transferência de conhecimentos, mas sim uma conscientizaçăo e testemunho de vida. Uma reformulaçăo significativa da educaçăo é inconcebível sem a correspondente transformaçăo do quadro social no qual as práticas educacionais da sociedade devem cumprir as suas vitais e historicamente importantes funçôes de mudança.

O Curso de Direito da FADIR/FURG visa à inclusăo social como princípio orientador das açôes educativas da Universidade. Pois, além de reafirmar a preocupaçăo e o compromisso com a democratizaçăo e a promoçâo da equidade de condiçôes de acesso ao conhecimento e de permanência de grupos em situaçâo de vulnerabilidade social e/ ou especial, nos mais diversos níveis de ensino, reconhecendo os limites e deficiências humanas como novas potencialidades criadoras de aprendizagem, na busca da formaçâo cidadă, na defesa da democracia e do direito a diferença; suas açôes de ensino, pesquisa e extensăo consideraram as demandas e os saberes sociais como forma de orientar os processos de formaçăo, de produçăo de conhecimentos e novas tecnologias, num diálogo permanente com o ecossistema nas suas diferentes manifestaçôes, de ordem natural, social, cultural ou histórica.

A tarefa imposta à Universidade do Século XXI, como bem frisou Boaventura, é produzir um conhecimento aproximado da realidade social, ou conhecimento prudente e encantado, que forneça elementos de transformaçăo social.

Este trabalho procurou apresentar algumas emergências expressas, curricular e extracurricularmente, em um Curso de Direito, cujo propósito é a formaçâo para a cidadania em uma sociedade livre, justa e democrática. Advoga-se que tendo como relevantes estas possibilidades poder-se-á construir uma educaçăo superior de/com qualidade social, horizontalizando e verticalizando a dupla obrigaçăo política na qual nos encontramos.

Por último, cabe destacar que a finalidade deste trabalho năo foi de oferecer respostas e soluçóes para essa problemática tâo desafiadora, mas sim tecer consideraçôes que possam contribuir para o despertar da complexidade das discussôes que se apresentam. 


\section{REFERÊNCIAS BIBLIOGRÁFICAS}

BAUMAN, Zygmunt. Identidade. Entrevista a Benedetto Vecchi. Traduçăo de Carlos Alberto Medeiros. Rio de Janeiro: Zahar, 2005.

BONAVIDES, Paulo. Ciência Política. Săo Paulo: Malheiros Editores, 2001.

BORGES, Edinaldo de Holanda. A teoria da democracia e o estado de direito. Sáo Paulo: NewBook, 2010.

FOUCAULT, Michael. Microfísica do poder. Sāo Paulo: Paz e Terra, 2014.

HARVEY, David. Cidades rebeldes: do direito à cidade à revoluçăo urbana. Săo Paulo: Martins Fontes, 2014.

MÉAZÁROS, István. A educaçáo para além do capital. Traduçâo de Isa Tavares. Sâo Paulo: Boitempo, 2005.

PALHARES, Isabela. PUC rejeita criaçăo da cátedra Foucault. Primeira universidade fora da França a abrigar áudios do pensador francês, reconhecido crítico da Igreja, pode ter de devolvê-los. Disponível em: <http://educacao.estadao.com.br/noticias/geral,puc -rejeita-criacao-da-catedra-foucault,1678638 > Acesso em 20 de outubro de 2015.

PINSKY, Jaime. Práticas de cidadania. Sáo Paulo: Contexto, 2004.

SANTOS, Boaventura de Sousa. A gramática do tempo: para uma nova cultura política. Sáo Paulo: Cortez, 2006.

Renovar a teoria crítica e reinventar a emancipaçăo social. Traduçâo Mouzar Benedito. Sāo Paulo: Boitempo, 2007.

. Portugal: ensaio contra a autoflagelaçáo. Săo Paulo: Cortez, 2011.

Poderá o direito ser emancipatório? Revista Crítica de Ciências Sociais. Coimbra, n 65, pp. 3-76, 2003.

SCIREA, Bruna. Quatro anos após atropelamento de ciclistas em Porto Alegre, avanços ainda săo tímidos. Manifestaçóes do Massa Crítica nesta semana devem marcar o aniversário do atropelamento e cobrar agilidade da Justiça. Disponível em: http:// zh.clicrbs.com.br/rs/porto-alegre/noticia/2015/02/quatro-anos-apos-atropelamentode-ciclistas-em-porto-alegre-avancos-ainda-sao-timidos-4706871.html Acesso em 20 de outubro de 2015.

WALSH, Chaterine. Interculturalidad, estado, sociedade: luchas (de)coloniales de nuestra época. Quito-Equador: Universidade Andina Simón Bolívar/Ediciones AbyaYala, 2009.

RECEBIDO EM: $17 / 01 / 2018$

APROVADO EM: 22/05/2018 